\title{
Impacts of three different microdiets on Florida Pompano, Trachinotus carolinus, weaning success, growth, fatty acid incorporation and enzyme activity
}

\author{
Marion R. Hauville ${ }^{a, c, *}$, José L. Zambonino-Infante ${ }^{b}$, Gordon Bell ${ }^{a}$, Hervé Migaud ${ }^{a}$, Kevan L. Main ${ }^{c}$
}

\author{
${ }^{\text {a }}$ Institute of Aquaculture, University of Stirling, Stirling, FK9 4LA Scotland, UK \\ ${ }^{b}$ Ifremer, Functional Physiology of Marine Organisms Unit, LEMAR-UMR 6539, 29200 Plouzané, France \\ ${ }^{c}$ Mote Marine Laboratory, Center for Marine and Freshwater Aquaculture Research, Sarasota, FL 34240, USA
}

*: Corresponding author : Marion R. Hauville, email address : $\underline{\text { mhauville@gmail.com }}$

\begin{abstract}
:
In this study, three microdiets were tested on weaning of Florida pompano larvae: Otohime, Gemma and a reference diet LR803. The experimental system was stocked with 11-day-old larvae, which were co-fed micro-diets and live food from $11 \mathrm{dph}$ to $17 \mathrm{dph}$ then micro-diets only until $28 \mathrm{dph}$. Survival from $11 \mathrm{dph}$ to $28 \mathrm{dph}$ was similar for all treatments, with an average of $33 \%$. At the end of the trial, the Gemma larvae were significantly longer and heavier than those larvae fed the other diets. Significant differences were observed in fatty acid composition of the diets and larvae between treatments. The Gemma larvae incorporated the lowest amount of eicosapentaenoic acid (EPA), docosahexaenoic acid (DHA) and arachidonic acid (ARA). However, they had the highest DHA/EPA and ARA/EPA ratios, which is in agreement with the concept that the proportions of polyunsaturated fatty acids could be of greater importance than their absolute amount. Results from the enzyme analysis suggest that fishmeal is suitable as the main protein source for Florida pompano larvae. This study gives new insights on Florida pompano early nutritional requirements and demonstrated the full functionality of the pancreas at 16 days post hatch, opening possibilities of an earlier weaning time.
\end{abstract}

\section{Highlights}

Survival was similar for Florida pompano larvae weaned on three different diets. Growth was enhanced by the Gemma diet compared to the two other diets. Essential fatty acids ratios appeared more important than absolute inclusion levels. Enzyme analyses showed the full functionality of the pancreas by 16 days post hatch.

Keywords: Enzyme ; Fatty acids ; Fish larvae ; Microdiets ; Trachinotus carolinus ; Weaning 


\section{1. INTRODUCTION}

39 The Florida pompano, Trachinotus carolinus, is found along the coasts of the eastern Atlantic 40 ocean and Gulf of Mexico, from Massachusetts down to Brazil, with the highest abundance

41 along the coast of Florida (Gilbert, 1986; Smith-Vaniz, 2002). Belonging to the Carangidae

42 family, it is a popular food and game fish (Iversen and Berry, 1969; Weirich et al., 2006).

43 The commercial fishery in the United States has remained small and the demand is

44 continuously increasing and higher than the supply (Weirich et al., 2006). In 2011, with only

45102.4 metric tons of commercial landing, the whole-fish dockside price reached US\$ 8.92/kg

46 (NOAA/NMFS, 2013). In addition to a high retail price and consumer demand, the Florida

47 pompano has a fast growth rate and can withstand high densities, making it a prime candidate

48 for aquaculture production (Iversen and Berry, 1969; Moe et al., 1968; Weirich et al., 2006).

49 However, difficulties in producing large quantities of juveniles have hindered the

50 development of Florida pompano farming and the development of reliable hatchery protocols

51 is essential (Cavalin and Weirich, 2009; Riley et al., 2009). One of the main challenges of

52 larval rearing is to provide adequate nutrition to support the fast growth and development of

53 larvae. Traditionally, most marine finfish larvae are first fed rotifers then Artemia until the

54 end of metamorphosis when they are slowly weaned on to a commercial dry diet (Rosenlund

55 et al., 1997). However, live food production is costly, time consuming and Artemia

56 nutritional value varies tremendously depending on strain, origin and even batches from the

57 same location (Conceição et al., 2010; Lavens and Sorgeloos, 2000). Rotifers and Artemia are

58 both deficient in essential fatty acids, which are a fundamental source of energy and

59 structural components for larval development (Sargent et al., 1997). Indeed, marine fish

60 larvae are unable to elongate and desaturate $18: 3 n-3$ and $18: 2 n-6$ to polyunsaturated fatty

61 acids (PUFAs) and these PUFAs must therefore be supplied by the diet (Bell, 2003; Sargent

62 et al., 1999b, 1989). In addition to a poor nutritional profile live food also transfers harmful 
63 bacteria to the larvae and the microbial control of live food cultures is a difficult procedure

64 (Olafsen, 2001).

65 To achieve an economical and reliable production of juveniles in marine finfish aquaculture it

66 is critical to develop micro-particulate diets that provide the adequate nutrition to the larvae.

67 Research from the past decade showed that unlike previously suggested (Dabrowski, 1984;

68 Kolkovski et al., 1993; Lauff and Hofer, 1984), fish larvae do possess the necessary enzymes

69 to digest an inert diet at the onset of exogenous feeding (Cahu and Zambonino-Infante,

70 2001). However, fish larvae have very different nutritional requirements compared to

71 juveniles. For example, it was found that dietary lipids (Coutteau et al., 1997) and protein

72 hydrolysates (Zambonino-Infante et al., 1997) are two crucial components for the growth and

73 development of larvae but are not essential for juveniles. Therefore, larval diets must be

74 specifically designed to meet these particular needs. In addition, the design of the diet must

75 take into consideration the reduced attraction of larvae for inert particles (Cox and Pankhurst,

76 2000; Fernandez-Diaz et al., 1994), the risk of leaching of nutrients due to the small surface

77 to volume ratio (Kvåle et al., 2006; Langdon, 2003) and the effects on water quality (Bonaldo

78 et al., 2011; Fletcher et al., 2007). While Cahu et al. (2003) successfully reared seabass

79 Dicentrarchus labrax on an experimental diet with total elimination of live food, a live food

80 period is still required for most marine fish larvae.

81 Co-feeding microdiets and live food has been shown to improve larval performances

82 compared to feeding microdiets or live food alone in many species such as red sea bream

83 Pagrus major and Japanese flounder Paralichthys olivaceus (Kanazawa et al., 1989), yellow-

84 finned black porgy Acanthopagrus latus (Leu et al., 1991), red drum Sciaenops ocellatus

85 (Holt, 1993), Atlantic cod Gadus morhua (Callan et al., 2003), barramundi Lates calcarifer

86 (Curnow et al., 2006) or Senegalese sole Solea senegalensis (Engrola et al., 2009). Two main

87 factors are contributing to the success of co-feeding protocols. First, live food visual and 
88 chemical stimulation facilitates the ingestion of the microdiet, conditioning the larvae to prey

89 on inert particles and allowing for an earlier weaning to dry feed (Canavate and Fernandez-

90 Diaz, 1999; Rosenlund et al., 1997). Second, live prey carry numerous nutritional factors

91 stimulating pancreatic enzyme secretions and endocrine responses which contributes to the

92 maturation of the digestive system (Kolkovski et al., 1997; Koven et al., 2001). The

93 maturation of the digestive system is characterized by the progressive decline of the early

94 mode of protein digestion and absorption (through pinocytosis and intracellular digestion)

95 and the simultaneous increase of extracellular digestion and membrane transport as the

96 enterocytes brush border membrane develops (Govoni et al., 1986). The study of the

97 pancreatic, cytosolic and brush border membrane enzymes give essential information on this

98 maturation process (Zambonino-Infante and Cahu, 2001).

99 The goal of this research was to gain knowledge on Florida pompano larvae nutritional

100 requirements and digestive abilities by studying the impact of co-feeding three different

101 microdiets on larval performances, lipid incorporation and digestive enzyme activity. 


\section{MATERIALS AND METHODS:}

$103 \quad 2.1$ Experimental set up

104 Eggs were obtained from a captive spawn at the Mote Marine Laboratory Aquaculture

105 Research Park in Sarasota, Florida. The broodstock population was collected in 2008 off the

106 southwest coast of Florida and conditioned using temperature and photoperiod control in a

$10725 \mathrm{~m}^{3}$ tank equipped with a recirculating filtration system. After 6 weeks under simulated

108 natural conditions, fish were sampled to check their reproductive status and females with 109 oocytes in late secondary growth $(410 \pm 21 \mu \mathrm{m}, \mathrm{n}=14$ females, 50 oocytes per females $)$ were 110 implanted with Ovaplant ${ }^{\circledR}$ at $50 \mu \mathrm{g} / \mathrm{kg}$ (Western Chemical Inc.). Eggs were incubated in a 111 100L conical hatching tank with an upwelling water flow recirculating with a $3.3 \mathrm{~m}^{3} \operatorname{tank}$ 112 equipped with a filtration system. After hatching, the water flow was reduced and the screen 113 of the overflow pipe removed to allow for a gentle release of the larvae in the tank and the

114 collection of dead embryos and egg casings at the bottom of the hatching tank.

115 Approximately 200,000 larvae were reared in the $3.3 \mathrm{~m}^{3}$ tank (temperature $26 \pm 1{ }^{\circ} \mathrm{C}$, salinity

$11635 \pm 1 \mathrm{~g} \mathrm{~L}^{-1}$, dissolved oxygen of $6 \pm 1 \mathrm{mg} \mathrm{L}^{-1}$ and $\mathrm{pH}$ of $\left.8 \pm 0.5\right)$ up to 11 days post hatch

117 (dph). Rotifers enriched with Algamac 3050 (Aquafauna Bio-Marine Inc., Hawthorne, CA,

118 USA) were fed to the larvae at $5 \mathrm{ml}^{-1}$ from 2 to $11 \mathrm{dph}$ and Artemia were introduced from 9

$119 \mathrm{dph}$ at $3 \mathrm{ml}^{-1}$. Up to $11 \mathrm{dph}$, the tank water was shaded with RotiGrow plus (Reed 120 Mariculture Inc, CA, USA) at 500,000 cells $\mathrm{L}^{-1}$. At dph 11, the water level in the production 121 tank was lowered and the larvae were collected and transferred to twelve $130 \mathrm{~L}$ experimental 122 tanks (870 larvae $\operatorname{tank}^{-1}$, counted manually, equivalent to 6-7 larvae $\mathrm{L}^{-1}$ ) corresponding to 123 three microdiets tested in quadruplicate: 1) Otohime (Commercial diet, Marubeni Nisshin

124 Feed Co. Japan), 2) Gemma (Commercial diet, Skretting, France) and 3) Larval Reference 125 Diet 803 - LR803 (Experimental diet, Agricultural Research Service, USA). The diet 126 ingredients are listed in Table 1. 
127 Larvae were co-fed one of three microdiets, rotifers at $3 \mathrm{ml}^{-1}$ and Artemia at $2 \mathrm{ml}^{-1}$ from 11 to

$12813 \mathrm{dph}$, followed by microdiet and Artemia at $1 \mathrm{ml}^{-1}$ until $16 \mathrm{dph}$. From 17 to $28 \mathrm{dph}$ (end of

129 the experiment), larvae were only fed microdiets through automatic feeders. Microdiets were

130 overfed to ensure larvae satiation and tanks were siphoned on a daily basis to maintain tank

131 hygiene. The experiment was ended at dph 28 when fish had completed metamorphosis, had

132 been fully weaned for over 10 days and required transfer to a larger system.

133 Larvae were sampled at 11, 16, 22, 26 and 28 dph to record standard length and body depth

134 (10 larvae $\operatorname{tank}^{-1}, 40$ treatment $\left.^{-1}\right)$. Body depth was measured from the insertion of the first

135 dorsal spine to the to the most ventral point on the base of the body, as pictured in Cavalin 136 and Weirich, 2009. Wet weight was recorded on 22, 26 and 28 dph only due to the very low 137 weight of the larvae prior to $22 \mathrm{dph}$ and the lack of analytical precision (10 larvae tank $\left.{ }^{-1}\right)$. At 13816,22 and $28 \mathrm{dph}, 10$ larvae from each tank were preserved for enzyme analysis. At the end 139 of the trial ( $28 \mathrm{dph}$ ), all fish were counted to determine survival and 10 larvae from each tank 140 were preserved for proximate and fatty acid analysis.

141

$142 \quad 2.2$ Enzyme analysis

143 Enzyme analyses were performed at the Functional Physiology of Marine Organisms Unit at

144 Ifremer, Brest, France. Larvae were dissected under a microscope on a glass plate at $0{ }^{\circ} \mathrm{C}$ to

145 separate the pancreatic segment from the intestinal segment as described in Cahu and

146 Zambonino-Infante (1994). Trypsin and amylase activities were assayed according to Holm

147 et al. (1988) and Métais and Bieth (1968) respectively. Enzymes of the brush border

148 membrane, alkaline phosphatase (AP) and leucine aminopeptidase (AN), were assayed

149 according to Bessey et al. (1946) and Maroux et al. (1973) respectively. Leucine-alanine

150 peptidase (leu-ala) assays were performed using the method of Nicholson and Kim (1975). 
151 Enzyme activities are expressed as specific activities (i.e. U/mg protein). Protein was

152 determined by the Bradford procedure (Bradford, 1976).

153

$154 \quad 2.4$ Proximate and lipid analyses

155 Proximate analyses were performed at the University of Stirling Institute of Aquaculture

156 Nutrition Group, in Stirling, Scotland. Proximate composition of microdiets and larvae at the

157 end of the trial were determined according to standard procedures (AOAC, 2000). Prior to

158 analysis, the larvae from each tank were pooled and minced. Moisture content was

159 determined by drying the samples at $105^{\circ} \mathrm{C}$ for $24 \mathrm{~h}$. Ash content was determined after $24 \mathrm{~h}$

160 in crucibles at $600{ }^{\circ} \mathrm{C}$. Crude protein content $(\mathrm{Nx6.25)}$ was determined using the automated

161 Kjeldahl method (Tecator Kjeltec Auto 1030 analyzer, Foss, Warrington, U.K). Crude lipid

162 content was determined after extraction according to Folch et al. (1957).

163 Lipid analyses were performed by the Fisheries and Mariculture Laboratory at the University

164 of Texas Marine Science Institute (UTMSI) in Port Aransas, Texas, USA. Lipids were

165 extracted according to Folch et al. (1957) and the fatty acid composition was determined by

166 gas-liquid chromatography after preparation of fatty acid methyl esters (FAMEs) according

167 to Morrison and Smith (1964). FAMEs were separated and quantified on a gas

168 chromatograph (Shimadzu GC-2014, Shimadzu Scientific Instruments, Columbia, MD, USA)

169 equipped with a Phenomenex ZB-WAX plus capillary column (30 m long, $0.53 \mathrm{~mm}$ internal

170 diameter, $1.0 \mu \mathrm{m}$ thickness; Phenomenex, Torrance, CA, USA) with on-column injection and

171 flame ionization detection, using helium as carrier gas $\left(4 \mathrm{~mL} \mathrm{~min}^{-1}\right)$ and injector and detector

172 temperatures of 250 and $260{ }^{\circ} \mathrm{C}$ respectively. Temperature was held at $160^{\circ} \mathrm{C}$ for 5 min then

173 increased up to $220^{\circ} \mathrm{C}$ at $3^{\circ} \mathrm{C}$ per minute and maintained at this temperature for 30 minutes.

174 FAMEs peaks were identified by comparison with known standards (Supelco, Inc.,

175 Bellefonte, Pennsylvania, USA). 


\section{$178 \quad 2.5$ Statistical analysis}

179 Statistical analysis was performed with MINITAB $^{\circledR}$ version 16.0 (Minitab Ltd., Coventry, 180 UK). Normality and homogeneity of variance were confirmed using Kolmogorov-Smirnov 181 test. Growth, body depth, wet weight and enzyme activities were compared using a General 182 Linear Model (GLM) with all time and treatment interactions being analyzed and significant 183 differences grouped by a Tukey post hoc test with $95 \%$ confidence. Survival, proximate 184 analysis and fatty acid data were arcsine square root transformed before a one-way ANOVA 185 followed by a Tukey post hoc test with $95 \%$ confidence. Linear regression was performed to 186 evaluate the incorporation of selected fatty acids from the diet into larval tissues. All data are 187 presented as mean \pm standard error of the mean (SEM) and level of statistical significance 188 was set at $\mathrm{P}<0.05$. 


\section{RESULTS}

190

$191 \quad$ 3.1 Survival

192 Survival during the experiment (from 11 to $28 \mathrm{dph}$ ) was similar for all treatments with $32.1 \pm$ $1931.2 \%, 32.6 \pm 0.8 \%$ and $33.3 \pm 0.9 \%$ for the fish fed the Gemma, LR803 and Otohime diets, 194 respectively (data not shown).

195

196

\subsection{Growth}

197 From 11 to 22 dph, larvae standard length was similar for all treatments (Fig. 1A). By 26 dph, 198 the Gemma larvae were significantly longer than the larvae fed the other diets. This trend 199 continued at 28 dph with Gemma > LR803 > Otohime larvae. In addition, from 26 to 28 dph, 200 the Otohime larvae exhibited a slower growth compared to the other treatments with an 201 average length at $28 \mathrm{dph}$ not statistically different from that of $26 \mathrm{dph}$ (Fig. 1A).

202 The first significant difference in body depth was observed at 16 dph with the Gemma larvae 203 being larger than the LR803 and Otohime larvae (Fig. 1B). The same trend was observed at $20428 \mathrm{dph}$.

205 From 26 dph onwards, the Gemma larvae were significantly heavier than the LR803 and 206 Otohime larvae (Fig. 1C). No difference was observed between the other two diets.

\section{$208 \quad 3.3$ Proximate analysis}

209 Lipid content was significantly different between microdiets (Table 2). Highest lipid content 210 was found in the LR803 diet $(26.8 \pm 0.1 \%)$, compared to the Otohime diet $(21.2 \pm 1.6 \%)$ 211 and the Gemma diet $(18.9 \pm 0.5 \%)$. At the end of the trial, no difference was observed in the 212 lipid content of the larvae. 
213 Protein content was significantly different between diets, with the Gemma diet containing $21457.6 \pm 0.1 \%$ of protein, a significantly higher content than that of the Otohime diet $(52.3 \pm$ $2150.1 \%)$ and the LR803 diet $(50.9 \pm 0.1 \%)$. The LR803 diet had a significantly lower protein 216 content compared to the two other diets. At the end of the trial, the Gemma and Otohime 217 larvae had similar protein contents $(16.3 \pm 0.3 \%$ and $16.1 \pm 0.3 \%$ respectively), significantly 218 higher than that of the LR803 larvae $(14.5 \pm 0.8 \%)$.

219 Moisture and ash content were significantly lower for the LR803 diet (respectively $5.6 \pm 0.1$ 220 and $3.7 \pm 0.1 \%$ ) compared to the other diets. Moisture content was similar for the Gemma 221 and Otohime diets $(6.4 \pm 0.1 \%)$ while ash content was significantly higher for the Otohime 222 diet compared to the Gemma diet (respectively $12.8 \pm 0.1 \%$ and $10.8 \pm 0.1 \%$ ). However, at 223 the end of the trial no difference was observed in the moisture and ash content of the larvae 224 fed the different treatments with an average moisture content of $61.2 \pm 0.3 \%$ and an average 225 ash content of $10.6 \pm 0.4 \%$ (Table 2).

\section{$227 \quad 3.4$ Fatty acid analysis}

228 Fatty acid profile of the larvae at the end of the trial was strongly influenced by the fatty acid 229 profile of the microdiets (Table 3). The main differences were observed in linoleic acid (LA), 230 ARA, EPA and DHA content.

231 LA content contrasted greatly between the diets, with LR803 and Gemma containing $19.84 \pm$ 2320.04 and $30.40 \pm 0.05 \%$ of LA respectively, as opposed to only $4.54 \pm 0.02 \%$ for Otohime 233 diet. LA content in the larvae was correlated $\left(\mathrm{R}^{2}=0.96\right)$ with the diet content. The LR803 and 234 Gemma larvae incorporated respectively $20.06 \pm 0.06 \%$ and $24.40 \pm 0.32 \%$ of LA, against $2354.51 \pm 0.13 \%$ for the Otohime larvae.

236 There was also a strong correlation $\left(\mathrm{R}^{2}=0.98\right)$ between the ARA content of the microdiets and 237 the ARA content of the larvae at the end of the trial. Highest ARA content was observed in 
238 the LR803 diet and larvae with respectively $0.55 \pm 0.00 \%$ and $0.59 \pm 0.01 \%$. The Otohime 239 diet had a similar ARA content $(0.54 \pm 0.01 \%)$, however the Otohime larvae incorporated 240 only $0.52 \pm 0.01 \%$ of ARA, significantly less than the LR803 larvae. A significantly lower 241 ARA content was observed in the Gemma diet and larvae, with respectively $0.34 \pm 0.00 \%$ 242 and $0.30 \pm 0.00 \%$.

243 The Otohime and LR803 diet and larvae contained the highest proportion of EPA with 244 respectively $10.79 \pm 0.05 \%$ and $9.01 \pm 0.08 \%$ for the diet and $7.28 \pm 0.08 \%$ and $6.10 \pm 0.13$ $245 \%$ for the larvae. The Gemma diet and larvae contained the lowest proportion of EPA with 246 respectively $4.12 \pm 0.03 \%$ and $2.21 \pm 0.04 \%$.

247 The Otohime diet contained the highest DHA content $(9.57 \pm 0.01 \%)$, significantly greater 248 than the Gemma diet DHA content $(7.32 \pm 0.05 \%)$ and the LR803 DHA content $(5.36 \pm 0.01$ $249 \%)$. The Otohime larvae incorporated the highest DHA content with $11.22 \pm 0.29 \%$. 250 However, even though the Gemma diet contained significantly higher DHA content than the 251 LR803 diet, the larvae fed these diets incorporated similar DHA contents $(7.37 \pm 0.11$ and $2527.12 \pm 0.13 \%$ ) for the Gemma and LR803 larvae respectively.

\section{$254 \quad 3.5$ Enzyme analyses}

255 Trypsin activity in the pancreatic segment did not vary for the Otohime larvae (Fig. 2A). 256 However, for the Gemma and LR803 larvae, the activity increased two-fold from 16 to 22 $257 \mathrm{dph}$, and then decreased from 22 to $28 \mathrm{dph}$ to levels similar to $16 \mathrm{dph}$. In the intestinal 258 segment, trypsin activity remained steady in the LR803 larvae throughout the trial period, 259 while a two-fold increase was observed for the Gemma larvae (Fig. 2B). A strong increase (4 260 fold) was observed in the Otohime larvae during the first half of the trial followed by a 261 decrease in activity from 22 to $28 \mathrm{dph}$. 
262 Amylase activity in the pancreatic segment exhibited a similar pattern for the larvae from all 263 treatments with a sharp decrease between 16 and $22 \mathrm{dph}$ and stabilization from 22 and $28 \mathrm{dph}$ 264 (Fig. 2C). In the intestinal segment, amylase specific activity did not vary significantly in the 265 Gemma and LR803 larvae (Fig. 2D). However, a two-fold increase was observed between 16 266 and $22 \mathrm{dph}$ in the Otohime larvae, that decrease between 22 and $28 \mathrm{dph}$, and reach levels 267 similar to $16 \mathrm{dph}$.

268 In the brush border membrane, AP specific activity decreased by half between 22 and $28 \mathrm{dph}$ 269 in the Otohime larvae (Fig. 3A). In contrast, AP activity in the Gemma larvae appeared to 270 increase between 22 and 28 dph though it was not statistically significant $(40 \%, \mathrm{p}=0.087)$. 271 Activity levels did not vary significantly for the LR803 larvae.

272 Activity levels of AN increased more than two-fold between 22 and $28 \mathrm{dph}$ in the Gemma 273 larvae (Fig. 3B). A $50 \%$ increase was also observed for the Otohime larvae, while no 274 significant difference was found in the LR803 larvae. During the trial period, an increase in 275 leu-ala activity was observed in larvae from all treatments although only significantly for the 276 Otohime and Gemma larvae (Fig. 3C). Between 16 and 22 dph, a two-fold increase was 277 observed in the Gemma larvae and a three-fold increase in the Otohime larvae. Between 22 278 and $28 \mathrm{dph}$, no significant variations were observed in the Gemma larvae while a $20 \%$ 279 decrease was observed in the Otohime larvae. 


\section{DISCUSSION}

281 This study showed that microdiet composition has a major impact on Florida pompano 282 larvae, influencing growth, fatty acid incorporation and activity of digestive enzymes.

283 Standard length, body depth and wet weight were all enhanced by the Gemma diet compared 284 to the Otohime and LR803 diet. Survival was similar for all treatments hence all diets were 285 able to support the growth of larvae after the end of the live food period.

286 No difference was observed in the lipid, moisture and ash content of the larvae despite 287 significant differences in the proximate composition of the microdiets. This shows that the 288 minimal lipid requirement was met and demonstrates the ability of Florida pompano larvae to 289 tolerate some variations in the lipid dietary intake. However, significant differences were 290 observed in the fatty acid profiles of the diets and larvae.

291 As previously mentioned, marine fish are unable to synthetize PUFAs de novo. The dietary 292 importance of PUFAs has been widely studied and reviewed (Sargent et al. 1989; Watanabe 293 and Kiron 1994; Izquierdo 1996; Sargent et al. 1999b; Sargent et al. 2002). However, major 294 uncertainties remain in PUFA dietary requirements as they vary between species and are 295 determined not only by the absolute amount of PUFAs, but also by their relative ratios 296 (Hamre et al., 2013; Izquierdo et al., 2000; Sargent et al., 1997).

297 DHA plays a critical role in the structure of cell membrane, especially for the correct 298 development of the visual and immune systems (Bell et al., 1995; Rodríguez et al., 1997; 299 Sargent, Bell, et al., 1999; Koven, 2003; Benítez-Santana et al., 2007). DHA and EPA 300 compete for the same enzyme to esterify fatty acid into phospholipid structures (Sargent, 301 Mcevoy, et al., 1999). Several studies have demonstrated that DHA has a more dominant role 302 in growth and membrane structure than EPA, suggesting that the relative proportions of DHA 303 and EPA may have a greater impact than the absolute amount, with the necessity of a greater 304 proportion of DHA than EPA (Glencross and Rutherford, 2011; Glencross, 2009; Reitan et 
305 al., 1994; Rodríguez et al., 1998; Watanabe, 1993). Our results agree with that hypothesis,

306 where the Otohime diet and larvae displayed the highest DHA and EPA contents but also 307 displayed the lowest growth. In contrast, the Gemma larvae, with the lowest DHA and EPA

308 contents but with a DHA:EPA ratio more than double of that of the Otohime or LR803

309 treatments, exhibited the fastest growth. At the end of the experiment, DHA:EPA ratios in the

310 larvae were significantly different from the ratios in the diet. The amount of EPA in the

311 larvae was significantly lower than that of the diet for all treatments. In contrast, the amount

312 of DHA was significantly higher in the Otohime and LR803 larvae than in the diets while it

313 did not vary in the Gemma treatment. This resulted in significantly higher DHA:EPA ratios

314 in the larvae than in the diet for all treatments. This suggests the ability of the larvae to

315 modulate, to some degree, the incorporation of EPA and some activity of the $\Delta 6$ desaturase,

316 even though the activity of this enzyme seems too low to convert enough EPA to DHA to

317 compensate the dietary deficiency (Vagner and Santigosa, 2011).

318 Among the HUFAs, DHA and EPA are the most abundant in marine fish eggs and tissues and

319 the dietary requirements for these two fatty acids have been widely studied in comparison to 320 ARA, though the latter plays a critical role in the development of the larvae (Sargent, Bell, et 321 al., 1999; Bell, 2003). ARA is specifically concentrated in fish eggs, attesting to its high 322 biological importance during the early phases of larval development (Bell et al., 1997).

323 EPA and ARA compete for the enzymes involved in the production of eicosanoids, with 324 eicosanoids produced from ARA being more biologically active, implying that, like DHA 325 and EPA, the ratio of ARA to EPA might be of greater importance than the absolute quantity 326 (Sargent, Mcevoy, et al., 1999; Tocher, 2003). Results from this experiment are consistent 327 with these earlier observations. Both the Gemma diet and larvae presented a lower ARA and 328 EPA content than for the other treatments. However, they presented the highest ARA:EPA 329 ratio and displayed the fastest growth. These results reinforce the fact that HUFA dietary 
requirements need to be considered as a whole, where the amount of each HUFA influences

331 the final ratios and the required metabolic pathways. An important difference in the fatty acid 332 profile of the different diets tested in this trial was the amount of LA. Despite the higher 333 levels of LA in the Gemma and LR803 diet, no increase in the content of the 334 desaturation/elongation pathway products was observed and it is likely that this fatty acid was 335 primarily used as a source of energy.

336 In addition to their impact on larvae development and fatty acid incorporation, microdiets can 337 strongly influence the development of the digestive system (Cahu and Zambonino-Infante, 338 2001). Marine fish larvae have to switch from a primary mode of digestion to an adult mode 339 of digestion; the maturational process is characterized by the acquisition of a progressive 340 efficient secretion of pancreatic enzymes, and the transition from a cytosolic to a brush 341 border membrane digestion at the intestinal level (Dabrowski, 1984; Ronnestad et al., 2013; 342 Zambonino-Infante et al., 1997).

343 An increase in growth and survival has been reported in correlation with an increase of both 344 pancreatic and intestinal enzyme activity in sea bass (Cahu and Zambonino-Infante, 1995), 345 sole (Ribeiro et al., 1999) and cod (Wold et al., 2007). Pancreatic enzymes specific activity 346 (activity per gram of protein) follow the same pattern in temperate marine fish, with an 347 increase during the first days/weeks of the life cycle depending on the species, followed by a 348 decrease to a constant level, not due to a decline in the amount of digestive enzymes, but as a 349 result of the increase of tissue proteins in the growing larvae (Zambonino-Infante and Cahu, 350 2001). Changes in the enzyme activity during ontogeny are genetically programmed, 351 however the diet influences the plateau level of enzymes and can delay or stop the digestive 352 system maturation process if inadequate (Cahu and Zambonino-Infante, 2001; Krogdahl and 353 Sundby, 1999). In this trial, the composition of the different diets impacted the development 354 of digestive functions of the larvae. Results from the amylase and trypsin analyses indicated 
355 that the pancreas is fully functional at $16 \mathrm{dph}$, which does not exclude that the pancreas may

356 be functional at an earlier date. Amylase specific activity is high in young fish larvae then 357 declines to a constant low level (Cahu and Zambonino-Infante, 1994; Péres et al., 1998;

358 Ribeiro et al., 1999), a pattern comparable to the decline of lactase expression during the 359 development of mammals (Freund et al., 1990). In the present study, the strong decline in 360 amylase activity was observed in the pancreatic segment from 16 dph for all treatments. In 361 the intestinal segment, amylase specific activity was significantly higher for larvae fed the 362 Otohime diet indicating a stimulation in amylase secretion likely due to the potato starch 363 contained in this diet. Indeed, starch content in the diet can influence amylase expression as 364 demonstrated in sea bass (Péres et al., 1998, 1996), red drum (Buchet et al., 2000) and yellow 365 croaker Pseudosciaena crocea (Ma et al., 2005).

366 Trypsin is responsible for the digestion of proteins during the early development of the larvae 367 and its activity is influenced by both the source and quantity of protein in the diet (Guerreiro 368 et al., 2010; Péres et al., 1996; Zambonino-Infante et al., 1996). In the present study, the 369 higher specific activity of trypsin observed in the intestinal segment of the larvae fed 370 Otohime suggests that the peak of specific activity in the pancreatic segment occurred before $37116 \mathrm{dph}$ and was likely a sign of a higher pancreatic secretory activity. The Gemma diet 372 includes the highest amount of protein followed by the Otohime diet and then the LR803 diet. 373 Therefore the increase of trypsin activity was not a result of the protein content of the diet but 374 probably the result of differences in the source and molecular form of the protein in the diet. 375 Indeed, each diet had a different main source of protein with the predominent ingredient 376 being krill meal in Otohime, fish meal (native protein and protein hydrolysate) in Gemma and 377 squid meal in LR803. Protein sources in microdiets have to provide an appropriate amino 378 acid profile and also have to be highly digestible given the larvae's poor digestive capacities; 379 in addition, they should have low water solubility due to the small surface to volume ratio of 
380 the diet particles (Nankervis and Southgate, 2006).

395 To facilitate proteins digestion and assimilation by the larvae, pre-digested proteins (protein 396 hydrolysates) are frequently incorporated into microdiets. Low to moderate levels of protein 397 hydrolysates have proven beneficial in several species including gilthead sea bream Sparus 398 aurata (Zambonino-Infante et al., 1997) and European sea bass (Cahu et al., 1999) while high 399 levels were detrimental in these same two species (Cahu et al., 1999; Kolkovski and Tandler, 400 2000). In the present study, the exact ingredient quantities and the presence or proportions of 401 protein hydrolysates in the diets are not known. Therefore, it is difficult to characterize the 402 effect of each source of protein on larvae development. However, the satisfactory results 403 obtained with the Gemma larvae suggest that fish meal including a mix of native proteins and 404 protein hydrolysates is an appropriate source of protein for pompano larvae. 
405 AP and AN are intestinal enzymes mainly located in the brush border membrane of

406 enterocytes while leu-ala peptidase is an intestinal enzyme mainly located in the cytosol of 407 enterocytes (Cahu et al., 1998). As the enterocytes mature and proliferate, the brush border

408 membrane develops and the associated enzyme activities increase while cytosolic enzyme 409 activities decline, indicating the establishment of the adult digestive system (Boglino et al., 410 2012; Zambonino-Infante and Cahu, 2001). In this trial, no decline in leu-ala activity was 411 observed in Gemma and LR803 larvae, while a peak was observed at 22 dph for Otohime 412 larvae but with an activity level at $28 \mathrm{dph}$ superior to $16 \mathrm{dph}$. Cytosolic digestion in Florida 413 pompano seems to remain elevated after the onset of BBM enzymes; in consequence, the 414 maturation of the enterocytes should be evaluated primarily through the activity of the BBM 415 enzymes (i.e. AP and AN). Very minor changes were observed in the specific activity of AP 416 and AN in the LR803 larvae, suggesting a delay in the maturation of the enterocytes in this 417 group. At $22 \mathrm{dph}$, highest $\mathrm{AP}$ and $\mathrm{AN}$ specific activities were observed in the Otohime 418 larvae. Contrariwise, this positive sign of enterocyte maturation was not confirmed at $28 \mathrm{dph}$, 419 particularly for AP. In contrast, larvae fed Gemma exhibited an appropriate maturation of the 420 BBM enzymes. This suggests that the Otohime diet was probably adequate for young larvae 421 before $22 \mathrm{dph}$, but failed to sustain an appropriate development of Florida pompano larvae 422 after this developmental date. Contrastingly, the larval development seemed to be more 423 continuous and balanced with the Gemma diet, as demonstrated by the growth and enzymatic 424 results.

425 In conclusion, this study brings new knowledge on Florida pompano dietary requirements 426 and digestive development. Results first suggest that a diet including $20 \%$ lipids, $55 \%$ 427 proteins, a DHA:EPA ratio greater than 1 and a ARA/EPA ratio of at least 0.08 is an 428 adequate weaning diet for Florida pompano since the Gemma diet, with similar 429 characteristics, promoted the best larvae performance in this experiment. Second, results 
430 from the enzyme analysis showed that the pancreas is fully functional by 16 dph suggesting 431 that weaning onto a dry diet could occur earlier than in the present study. Additional research 432 is needed to determine more precisely the Florida pompano larval nutritional requirements 433 . Indeed, even though lipids are one of the most important 434 nutritional factors known to affect larvae growth and survival, numerous other macro and 435 micro-nutrients can either enhanced or inhibit larvae development. This includes ingredients 436 and supplementations present in low quantities in the diets tested in this study such as taurine 437 (Pinto et al., 2013, 2010; Schreck et al., 2012), yeast (Tovar-Ramírez et al., 2010, 2004) or 438 vitamins and minerals (Hamre et al., 2013; Moren et al., 2011) which were beyond the scope 439 of this study. However, the present results give a baseline of a suitable weaning diet, which 440 can be used in future trials to determine the optimal weaning time for Florida pompano. 


\section{ACKNOWLEDGEMENTS}

443 The authors would like to thank the research team at the Mote Marine Laboratory

444 Aquaculture Park, as well as Dr Frederic Barrows from the Agricultural Research Service at 445 the United States Department of Agriculture for manufacturing the reference diet, Nick King 446 from Skretting for donating the Gemma diet, Cynthia Faulk from the Fisheries and 447 Mariculture Laboratory at the University of Texas Marine Science Institute for her help with 448 the lipid analysis, James Dick and Graeme McWinnie from the Institute of Aquaculture at the 449 University of Stirling for their assistance with the proximate analyses and Christine Huelvan 450 from the Functional Physiology of Marine Organisms Unit at IFREMER for her assistance 451 with the enzyme analyses. This study was supported by the University of Stirling, the Florida 452 Department of Agriculture and Consumer Services, Adam H. Putnam, Commissioner, 453 Contract No. 017138, and the National Sea Grant College Program of the U.S. Department of 454 Commerce's National Oceanic and Atmospheric Administration (NOAA), Grant No. 455 NA10OAR4170079. The views are those of the authors and do not necessarily reflect the 456 view of these organizations.

457 


\section{REFERENCES}

459 AOAC, 2000. Official methods of analysis. Association of Official Analytical Chemists, 460 Gaithersburg, Maryland, USA.

461 Bell, G., 2003. Arachidonic acid in aquaculture feeds: current status and future opportunities. $462 \quad$ Aquaculture 218, 491-499.

463 Bell, G., Farndale, B.M., Bruce, M., Navas, J.M., Carillo, M., 1997. Effects of broodstock 464 dietary lipid on fatty acid compositions of eggs from sea bass (Dicentrarchus labrax). $465 \quad$ Aquaculture 149, 107-119.

Bell, M. V, Batty, R.S., Dick, J.R., Fretwell, K., Navarro, J.C., Sargent, J.R., 1995. Dietary deficiency of docosahexaenoic acid impairs vision at low light intensities in juvenile herring (Clupea harengus L.). Lipids 30, 443-449.

469

470

471

472 473

474 475 476

477 478

Benítez-Santana, T., Masuda, R., Juárez Carrillo, E., Ganuza, E., Valencia, Hernández-Cruz, C.M., Izquierdo, M.S., 2007. Dietary n-3 HUFA deficiency induces a reduced visual response in gilthead seabream Sparus aurata larvae. Aquaculture 264, 408-417.

Bessey, O.A., Lowry, O.H., Brock, M.J., 1946. A method for the rapid determination of alkaline phosphates with five cubic millimeters of serum. J. Biol. Chem. 164, 321-9.

Boglino, A., Darias, M.J., Ortiz-Delgado, J.B., Özcan, F., Estévez, A., Andree, K.B., Hontoria, F., Sarasquete, C., Gisbert, E., 2012. Commercial products for Artemia enrichment affect growth performance, digestive system maturation, ossification and incidence of skeletal deformities in Senegalese sole (Solea senegalensis) larvae. Aquaculture 324-325, 290-302. 
479 Bonaldo, A., Parma, L., Badiani, A., Serratore, P., Gatta, P.P., 2011. Very early weaning of 480 common sole (Solea solea L.) larvae by means of different feeding regimes and three 481 commercial microdiets: Influence on performances, metamorphosis development and 482 tank hygiene. Aquaculture 321, 237-244.

483 Bradford, M.M., 1976. A rapid and sensitive method for the quantitation of microgram 484 quantities of protein utilizing the principle of protein-dye binding. Anal. Biochem. 72, $485 \quad 248-54$.

486 Buchet, V., Zambonino-Infante, J.L., Cahu, C.L., 2000. Effect of lipid level in a compound 487 diet on the development of red drum (Sciaenops ocellatus) larvae. Aquaculture 184, $488 \quad 339-347$.

489 Cahu, C.., Zambonino Infante, J.., Quazuguel, P., Le Gall, M.., 1999. Protein hydrolysate vs. 490 fish meal in compound diets for 10-day old sea bass Dicentrarchus labrax larvae. $491 \quad$ Aquaculture 171, 109-119.

492 Cahu, C.L., Zambonino-Infante, J.L., 1994. Early weaning of sea bass (Dicentrarchus 493 labrax) larvae with a compound diet: Effect on digestive enzymes. Comp. Biochem. 494 Physiol. Part A Physiol. 109, 213-222.

495 Cahu, C.L., Zambonino-Infante, J.L., 1995. Effect of the molecular form of dietary nitrogen 496 supply in sea bass larvae: Response of pancreatic enzymes and intestinal peptidases. 497 Fish Physiol. Biochem. 14, 209-214.

498 Cahu, C.L., Zambonino-Infante, J.L., 2001. Substitution of live food by formulated diets in 499 marine fish larvae. Aquaculture 200, 161-180. 
500 Cahu, C.L., Zambonino-Infante, J.L., Barbosa, V., 2003. Effect of dietary phospholipid level

501 and phospholipid:neutral lipid value on the development of sea bass (Dicentrarchus

502 labrax) larvae fed a compound diet. Br. J. Nutr. 90, 21-28.

503 Cahu, C.L., Zambonino-Infante, J.L., Peres, A., Quazuguel, P., Gall, M.M. Le, 1998. Algal 504 addition in sea bass (Dicentrarchus labrax) larvae rearing $\square$ : effect on digestive 505 enzymes. Aquaculture 161, 479-489.

506 Callan, C., Jordaan, A., Kling, L.., 2003. Reducing Artemia use in the culture of Atlantic cod 507 (Gadus morhua). Aquaculture 219, 585-595.

508 Canavate, J.P., Fernandez-Diaz, C., 1999. Influence of co-feeding larvae with live and inert 509 diets on weaning the sole Solea senegalensis onto commercial dry feeds. Aquaculture $510 \quad 174,255-263$.

511 Cavalin, F.G., Weirich, C.R., 2009. Larval performance of aquacultured Florida pompano 512 (Trachinotus carolinus) fed rotifers (Brachionus plicatilis) enriched with selected 513 commercial diets. Aquaculture 292, 67-73.

514 Conceição, L.E.C., Yúfera, M., Makridis, P., Morais, S., Dinis, M.T., 2010. Live feeds for 515 early stages of fish rearing. Aquac. Res. 41, 613-640.

516 Coutteau, P., Geurden, I., Camara, M.R., Bergot, P., Sorgeloos, P., 1997. Review on the 517 dietary effects of phospholipids in fish and crustacean larviculture. Aquaculture 155, $518 \quad 149-164$.

519 Cox, E.S., Pankhurst, P.M., 2000. Feeding behaviour of greenback flounder larvae, 520 Rhombosolea tapirina (Günther) with differing exposure histories to live prey. $521 \quad$ Aquaculture 183, 285-297. 
522 Curnow, J., King, J., Bosmans, J., Kolkovski, S., 2006. The effect of reduced Artemia and 523 rotifer use facilitated by a new microdiet in the rearing of barramundi Lates calcarifer $524 \quad$ (BLOCH) larvae. Aquaculture 257, 204-213.

525 Dabrowski, K., 1984. The feeding of fish larvae $\square$ : present « $\square$ state of the art $\square$ » and 526 perspectives. Reprod. Nutr. Dev. 24, 807-833.

527 Engrola, S., Figueira, L., Conceição, L.E.C., Gavaia, P.J., Ribeiro, L., Dinis, M.T., 2009. Co528 feeding in Senegalese sole larvae with inert diet from mouth opening promotes growth 529 at weaning. Aquaculture 288, 264-272.

530 Fernandez-Diaz, C., Pascual, E., Yúfera, M., 1994. Feeding behaviour and prey size selection 531 of gilthead seabream, Sparus aurata, larvae fed on inert and live food. Mar. Biol. 118, $532 \quad 323-328$.

533 Fletcher, R.C., Roy, W., Davie, A., Taylor, J., Robertson, D., Migaud, H., 2007. Evaluation 534 of new microparticulate diets for early weaning of Atlantic cod (Gadus morhua): 535 Implications on larval performances and tank hygiene. Aquaculture 263, 35-51.

536 Folch, J., Lees, M., Sloane Stanley, G.H., 1957. A simple method for the isolation and 537 purification of total lipides from animal tissues. J. Biol. Chem. 226, 497-509.

538 Freund, J.N., Torp, N., Duluc, I., Foltzer-Jourdainne, C., Danielsen, M., Raul, F., 1990. 539 Comparative expression of the mRNA for three intestinal hydrolases during postnatal 540 development in the rat. Cell. Mol. Biol. 36, 729-36.

541 Gilbert, C., 1986. Species profiles: life histories and environmental requirements of coastal 542 fishes and invertebrates (south Florida): Florida pompano. Biol. Rep. 82, 24. 
543 Glencross, B., Rutherford, N., 2011. A determination of the quantitative requirements for 544 docosahexaenoic acid for juvenile barramundi (Lates calcarifer). Aquac. Nutr. 17, 545 e536-e548.

546 Glencross, B.D., 2009. Exploring the nutritional demand for essential fatty acids by 547 aquaculture species. Rev. Aquac. 1, 71-124.

548 Govoni, J.J., Boehlert, G.W., Watanabej, Y., 1986. The physiology of digestion in fish 549 larvae. Environ. Biol. Fishes 16, 59-77.

550 Guerreiro, I., de Vareilles, M., Pousão-Ferreira, P., Rodrigues, V., Dinis, M.T., Ribeiro, L., 551 2010. Effect of age-at-weaning on digestive capacity of white seabream (Diplodus 552 sargus). Aquaculture 300, 194-205.

553 Hamre, K., Yúfera, M., Rønnestad, I., Boglione, C., Conceição, L.E.C., Izquierdo, M., 2013. 554 Fish larval nutrition and feed formulation: knowledge gaps and bottlenecks for advances 555 in larval rearing. Rev. Aquac. 5, S26-S58.

556 Holm, H., Hanssen, L.E., Krogdahl, A., Florholmen, J., 1988. High and low inhibitor soybean 557 meals affect human duodenal proteinase activity differently: in vivo comparison with 558 bovine serum albumin. J. Nutr. 118, 515-520.

559 Holt, G.J., 1993. Feeding Larval Red Drum on Microparticulate Diets in a Closed 560 Recirculating Water System. J. World Aquac. Soc. 24, 225-230.

561 Iversen, E.S., Berry, F.H., 1969. Fish Mariculture: Progress and Potential. Proceeding Gulf $562 \quad$ Caribb. Fish. Inst. 21, 163-176. 
563 Izquierdo, M.S., 1996. Review Article Essential fatty acid requirements of cultured marine 564 fish larvae. Aquac. Nutr. 2, 183-191.

565 Izquierdo, M.S., Socorro, J., Arantzamendi, L., Hernández-Cruz, C.M., 2000. Recent 566 advances in lipid nutrition in fish larvae. Fish Physiol. Biochem. 22, 97-107.

567 Kanazawa, A., Koshio, S., Teshima, S.-I., 1989. Growth and survival of larval Red Sea 568 Bream Pagrus major and Japanese Flounder Paralichthys olivaceus fed microbound 569 diets. J. World Aquac. Soc. 20, 31-37.

570 Kolkovski, S., Koven, W., Tandler, A., 1997. The mode of action of Artemia in enhancing 571 utilization of microdiet by gilthead seabream Sparus aurata larvae. Aquaculture 155, $572 \quad 193-205$.

573 Kolkovski, S., Tandler, A., 2000. The use of squid protein hydrolysate as a protein source in 574 microdiets for gilthead seabream Sparus aurata larvae. Aquac. Nutr. 6, 11-15.

575 Kolkovski, S., Tandler, A., Kissil, G.W., Gertler, A., 1993. The effect of dietary exogenous 576 digestive enzymes on ingestion, assimilation, growth and survival of gilthead seabream 577 (Sparus aurata, Sparidae, Linnaeus) larvae. Fish Physiol. Biochem. 12, 203-209.

578 Koven, W., 2003. Key factors influencing juvenile quality in mariculture: a review. Isr. J. $579 \quad$ Aquac. 55, 283-297.

580 Koven, W., Kolkovski, S., Hadas, E., Gamsiz, K., Tandler, a, 2001. Advances in the 581 development of microdiets for gilthead seabream, Sparus aurata: a review. Aquaculture $582 \quad 194,107-121$. 
583 Krogdahl, A., Sundby, A., 1999. Characteristics of pancreatic function in fish, in: 584 Pierzynowski, S.G., Zabielski, R. (Eds.), Biology of the Pancreas in Growing Animals. $585 \quad$ Elsevier Science, Amsterdam, pp. 437-458.

586 Kvåle, A., Yúfera, M., Nygård, E., Aursland, K., Harboe, T., Hamre, K., 2006. Leaching 587 properties of three different micropaticulate diets and preference of the diets in cod 588 (Gadus morhua L.) larvae. Aquaculture 251, 402-415.

589 Langdon, C., 2003. Microparticle types for delivering nutrients to marine fish larvae. $590 \quad$ Aquaculture 227, 259-275.

591 Lauff, M., Hofer, R., 1984. Proteolytic enzymes in fish development and the importance of 592 dietary enzymes. Aquaculture 37, 335-346.

593 Lavens, P., Sorgeloos, P., 2000. The history, present status and prospects of the availability 594 of Artemia cysts for aquaculture. Aquaculture 181, 397-403.

595 Leu, M.-Y., Liou, C.-H., Wu, C.-H., 1991. Feasibility of using micro-coated diet fed to larval 596 yellow-finned black porgy, Acanthopagrus Latus (Houttuyn). J. Fish. Soc. Taiwan 18, $597 \quad 287-294$.

598 Ma, H., Cahu, C.L., Zambonino-Infante, J.L., Yu, H., Duan, Q., Le Gall, M.-M., Mai, K., 599 2005. Activities of selected digestive enzymes during larval development of large 600 yellow croaker (Pseudosciaena crocea). Aquaculture 245, 239-248.

601 Maroux, S., Louvard, D., Barath, J., 1973. The aminopeptidase from hog intestinal brush 602 border. Biochim. Biophys. Acta - Enzymol. 321, 282-295. 
603 Métais, P., Bieth, J., 1968. Determination of alpha-amylase by a microtechnic. Ann. Biol. 604 Clin. (Paris). 26, 133-42.

605 Moe, M.A.J., Lewis, R.H., Ingle, R.M., 1968. Pompano mariculture: preliminary data and 606 basic considerations. Florida State Board Conserv. Mar. Res. Lab. - Tech. Ser. 55, 65.

607 Moren, M., Waagbo, R., Hamre, K., 2011. Micronutrients, in: Holt, G.J. (Ed.), Larval Fish $608 \quad$ Nutrition. Wiley-Blackwell, Oxford, UK.

609 Morrison, W.R., Smith, L.M., 1964. Preparation of fatty acid methyl esters and 610 dimethylacetals from lipids with boron fluoride--methanol. J. Lipid Res. 5, 600-608.

611 Nankervis, L., Southgate, P.C., 2006. An integrated assessment of gross marine protein 612 sources used in formulated microbound diets for barramundi (Lates calcarifer) larvae. $613 \quad$ Aquaculture 257, 453-464.

614 Nicholson, J.A., Kim, Y.S., 1975. A one-step 1-amino acid oxidase assay for intestinal 615 peptide hydrolase activity. Anal. Biochem. 63, 110-117.

616 NOAA/NMFS, 2013. Annual Commercial Landing Statistics [WWW Document]. URL 617 http://www.st.nmfs.noaa.gov/commercial-fisheries/commercial-landings/annual-

618 landings/index

619 Olafsen, J.A., 2001. Interactions between fish larvae and bacteria in marine aquaculture. $620 \quad$ Aquaculture 200, 223-247.

621 Péres, A., Cahu, C.L., Zambonino-Infante, J.L., Gall, M.M., Quazuguel, P., 1996. Amylase 622 and trypsin responses to intake of dietary carbohydrate and protein depend on the 
623 developmental stage in sea bass (Dicentrarchus labrax) larvae. Fish Physiol. Biochem.

$624 \quad 15,237-242$.

625 Péres, A., Zambonino-Infante, J.L., Cahu, C.L., 1998. Dietary regulation of activities and 626 mRNA levels of trypsin and amylase in sea bass ( Dicentrarchus labrax ) larvae. Fish 627 Physiol. Biochem. 19, 145-152.

628 Pinto, W., Figueira, L., Ribeiro, L., Yúfera, M., Dinis, M.T., Aragão, C., 2010. Dietary 629 taurine supplementation enhances metamorphosis and growth potential of Solea 630 senegalensis larvae. Aquaculture 309, 159-164.

631 Pinto, W., Rønnestad, I., Dinis, M.T., Aragão, C., 2013. Taurine and fish development: 632 insights for the aquaculture industry, in: Idrissi, A. El, L'Amoreaux, W.J. (Eds.), 633 Taurine 8. Springer New York, pp. 329-34.

634 Reitan, K., Rainuzzo, J., Olsen, Y., 1994. Influence of lipid composition of live feed on 635 growth, survival and pigmentation of turbot larvae. Aquac. Int. 2, 33-48.

636 Ribeiro, L., Zambonino-Infante, J.L., Cahu, C.L., Dinis, M.T., 1999. Development of 637 digestive enzymes in larvae of Solea senegalensis, Kaup 1858. Aquaculture 179, 465$638 \quad 473$.

639 Riley, K., Charles, W., Cerino, D., 2009. Development and growth of hatchery-reared larval $640 \quad$ Florida pompano ( Trachinotus carolinus ). Fish. Bull. 107, 318-328.

641 Rodríguez, C., Pérez, J.A., Badía, P., Izquierdo, M.S., Fernández-Palacios, H., Lorenzo 642 Hernandez, A., 1998. The n-3 highly unsaturated fatty acids requirements of gilthead 643 seabream (Sparus aurata L .) larvae when using an appropriate DHA EPA ratio in the 644 diet. Aquaculture 169, 9-23. 
645 Rodríguez, C., Pérez, J.A., Diaz, M., Izquierdo, M.S., Fernández-Palacios, H., Lorenzo

646 Hernandez, A., 1997. Influence of the EPA / DHA ratio in rotifers on gilthead seabream

647 (Sparus aurata) larval development. Aquaculture 150, 77-89.

648 Ronnestad, I., Manuel, Y., Ueberschar, B., Ribeiro, L., Sæle, Ø., Boglione, C., 2013. Feeding 649 behaviour and digestive physiology in larval fish $\square$ : current knowledge, and gaps and 650 bottlenecks in research. Rev. Aquac. 5, S59-S98.

651 Rosenlund, G., Stoss, J., Talhot, C., 1997. Co-feeding marine fish larvae with inert and live 652 diets. Aquaculture 155, 183-191.

653 Sargent, J.R., Bell, G., McEvoy, L.A., Tocher, D.R., Estévez, A., 1999a. Recent 654 developments in the essential fatty acid nutrition of fish. Aquaculture 177, 191-199.

655 Sargent, J.R., Henderson, R.J., Tocher, D.R., 1989. The lipids, in: Halver, J.E. (Ed.), Fish $656 \quad$ Nutrition. Interscience Publishers, New York, pp. 153-218.

657 Sargent, J.R., Mcevoy, L., Estévez, A., Bell, G., Bell, M. V, Henderson, R.J., Tocher, D.R., 658 1999b. Lipid nutrition of marine fish during early development: current status and future 659 directions. Aquaculture 179, 217-229.

660 Sargent, J.R., McEvoy, L.A., Bell, G., 1997. Requirements, presentation and sources of 661 polyunsaturated fatty acids in marine fish larval feeds. Aquaculture 155, 117-127.

662 Sargent, J.R., Tocher, D.R., Bell, G., 2002. The Lipids, in: Halver, J., Hardy, R. (Eds.), Fish $663 \quad$ Nutrition. Elsevier, San Diego, pp. 181-257. 
664 Schreck, C.B., Björnsson, B.T., McCormick, S.D., McGinnity, P., Stefansson, S.O., Ueda, 665 H., Donaldson, E.M., Salze, G., McLean, E., Craig, S.R., 2012. Dietary taurine enhances 666 growth and digestive enzyme activities in larval cobia. Aquaculture 362, 44-49.

667 Smith-Vaniz, W.F., 2002. Carangidae, in: Carpenter, K.E. (Ed.), The Living Marine 668 Resources of the Western Central Atlantic, Volume 3: Bony Fishes Part 2 669 (Opistognathidae to Molidae). FAO Species Identification Guide for Fishery Purposes 670 and American Society of Ichthyologists and Herpetologists Special Publication No. 5, $671 \quad$ Rome, pp. 1426-1440.

672 Tocher, D.R., 2003. Metabolism and Functions of Lipids and Fatty Acids in Teleost Fish. 673 Rev. Fish. Sci. 11, 107-184.

674 Tovar-Ramírez, D., Mazurais, D., Gatesoupe, F.-J., Quazuguel, P., Cahu, C.L., Zambonino675 Infante, J.L., 2010. Dietary probiotic live yeast modulates antioxidant enzyme activities 676 and gene expression of sea bass (Dicentrarchus labrax) larvae. Aquaculture 300, 142$677 \quad 147$.

678 Tovar-Ramírez, D., Zambonino Infante, J., Cahu, C., Gatesoupe, F.., Vázquez-Juárez, R., 679 2004. Influence of dietary live yeast on European sea bass (Dicentrarchus labrax) larval 680 development. Aquaculture 234, 415-427.

681 Vagner, M., Santigosa, E., 2011. Characterization and modulation of gene expression and 682 enzymatic activity of delta-6 desaturase in teleosts: A review. Aquaculture 315, 131683 143.

684 Watanabe, T., 1993. Importance of Docosahexaenoic Acid in Marine Larval Fish. J. World 685 Aquac. Soc. 24, 152-161. 
686 Watanabe, T., Kiron, V., 1994. Prospects in larval fish dietetics. Aquaculture 124, 223-251.

687 Weirich, C.R., Groat, D.R., Reigh, R.C., Chesney, J., Malone, R.F., 2006. Effect of Feeding 688 Strategies on Production Characteristics and Body Composition of Florida Pompano 689 Reared in Marine Recirculating Systems. N. Am. J. Aquac. 68, 330-338.

690 Wold, P.-A., Hoehne-Reitan, K., Cahu, C.L., Zambonino-Infante, J.L., Rainuzzo, J., 691 Kjørsvik, E., 2007. Phospholipids vs. neutral lipids: Effects on digestive enzymes in 692 Atlantic cod (Gadus morhua) larvae. Aquaculture 272, 502-513.

693 Zambonino-Infante, J.L., Cahu, C.L., 2001. Ontogeny of the gastrointestinal tract of marine 694 fish larvae. Comp. Biochem. physiolgy Part C 130, 477-87.

695 Zambonino-Infante, J.L., Cahu, C.L., Peres, A., 1997. Partial substitution of di- and 696 tripeptides for native proteins in sea bass diet improves Dicentrarchus labrax larval 697 development. J. Nutr. 127, 608-14.

698 Zambonino-Infante, J.L., Cahu, C.L., Peres, A., Quazuguel, P., Gall, M.M. Le, 1996. Sea 699 bass (Dicentrarchus labrax) larvae fed different Artemia rations $\square$ : growth , pancreas 700 enzymatic response and development of digestive functions. Aquaculture 139, 129-138.

701 


\section{Figure headlines}

704

705 Figure 1. Standard length (A) Body depth (B) and wet weight (C) of Florida pompano larvae 706 fed three different diets. Values are mean \pm SEM $(n=4$ tanks, 10 larvae per tank and time 707 point). Letters indicate significant differences between treatments and time points (Tukey 708 test, $\mathrm{p}<0.05)$.

709

710 Figure 2: Specific activity (mU/mg protein) of trypsin and amylase in the pancreatic segment 711 and intestinal segment of Florida pompano larvae fed different microdiets. Values are mean \pm 712 SEM ( $\mathrm{n}=4$ tanks, 10 pooled larvae per tank and time point). Letters indicate significant 713 differences between treatments and time points (Tukey test, $\mathrm{p}<0.05$ ).

714

715 Figure 3. Specific activity (mU/mg protein) of alkaline phosphatase and leucine 716 aminopeptidase in the brush border membrane (A and B), and of leucine alanine peptidase in 717 the intestinal segment (C) of Florida pompano larvae fed different microdiets. Values are 718 mean \pm SEM $(n=4$ tanks, 10 pooled larvae per tank and time point). Letters indicate 719 significant differences between treatments and time points (Tukey test, $\mathrm{p}<0.05$ ). 


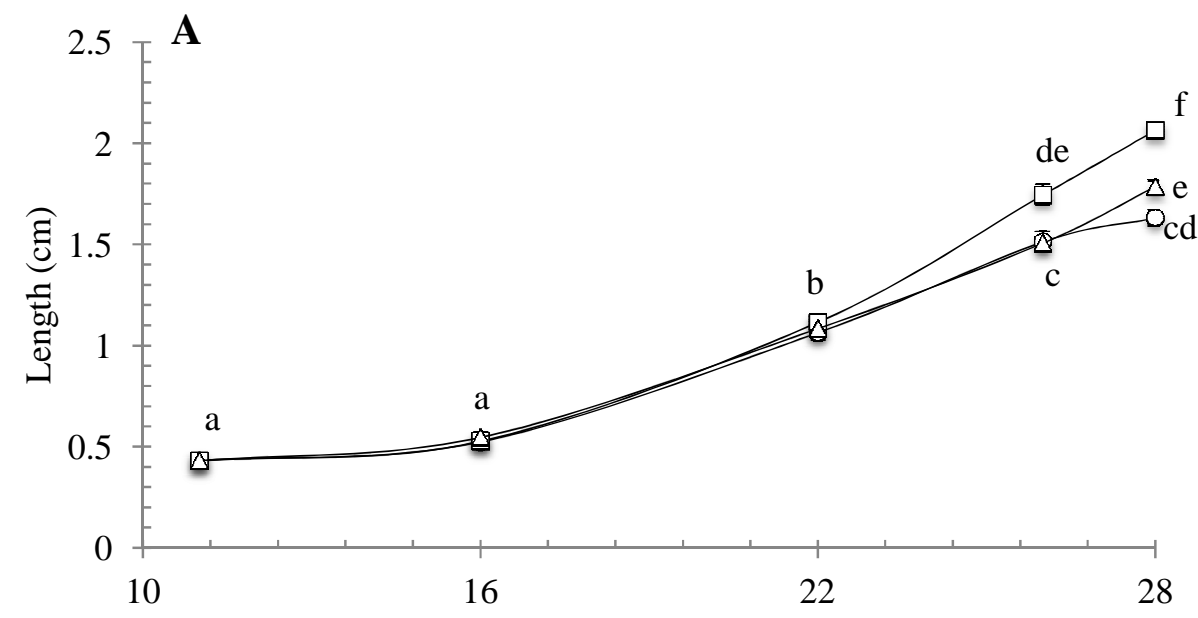

721

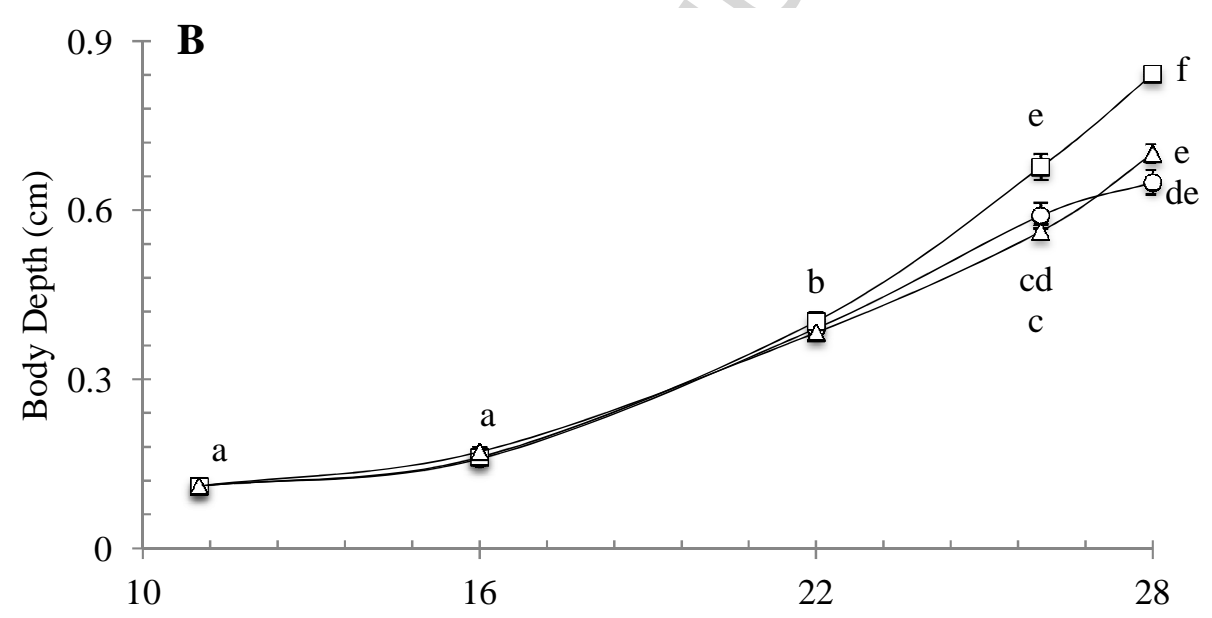

722

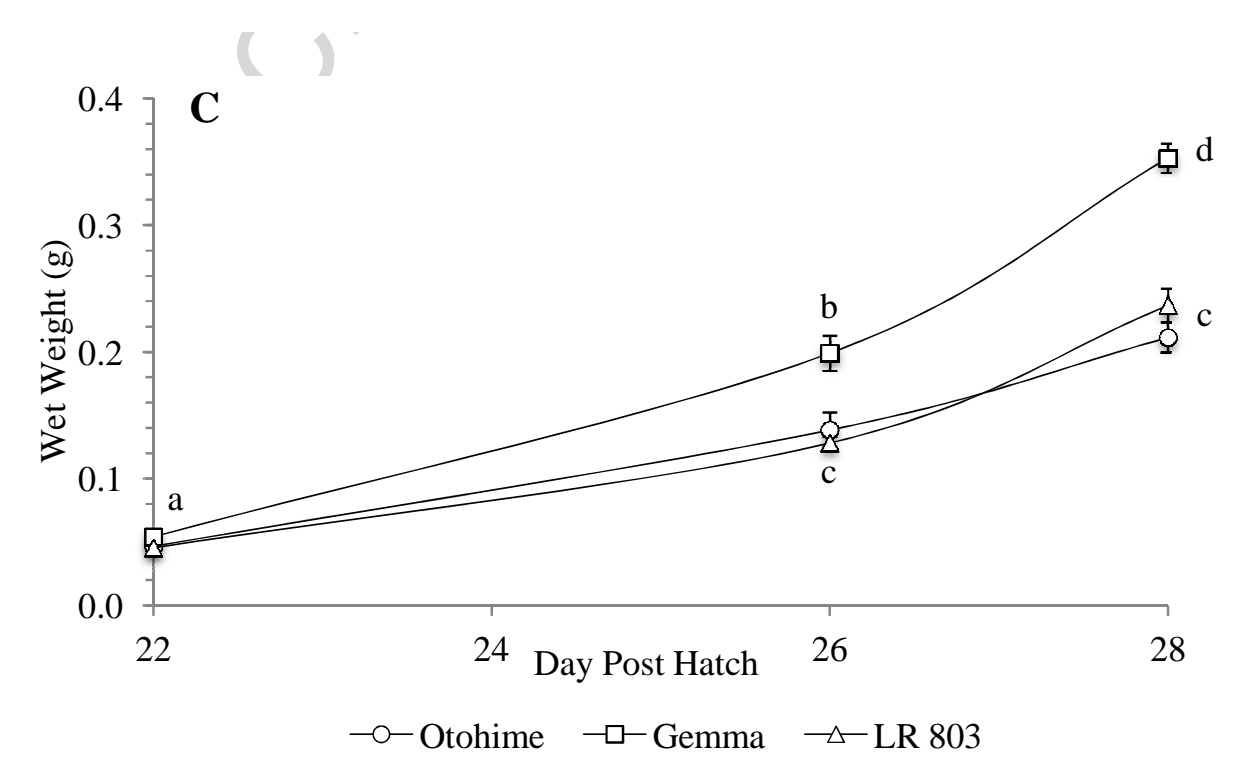

723

724 Figure 1 
A) Trypsin Pancreatic Segment

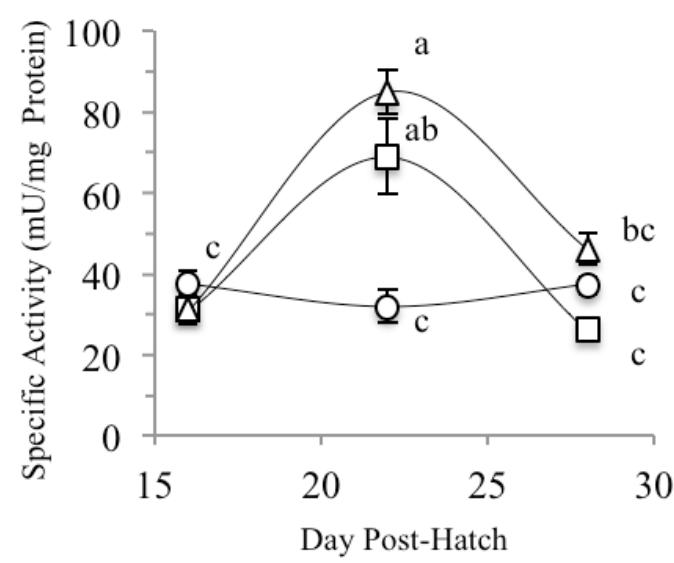

C) Amylase Pancreatic Segment

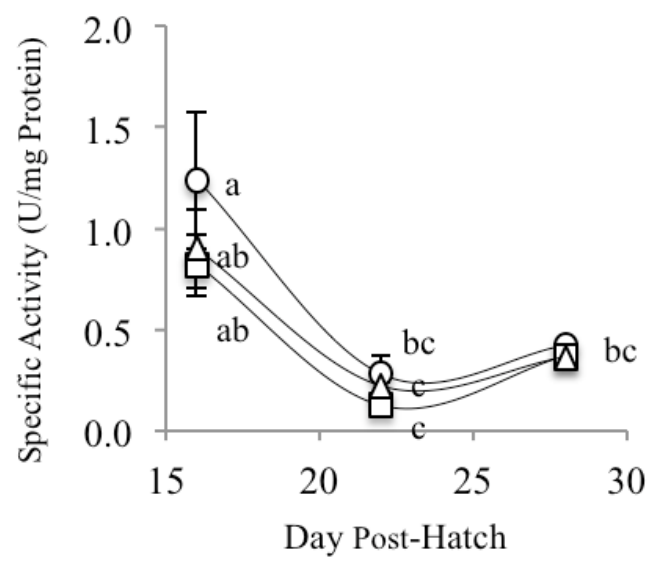

726

$$
\text { -O-Otohime } \quad \square \text {-Gemma } \quad-\text { LR803 }
$$

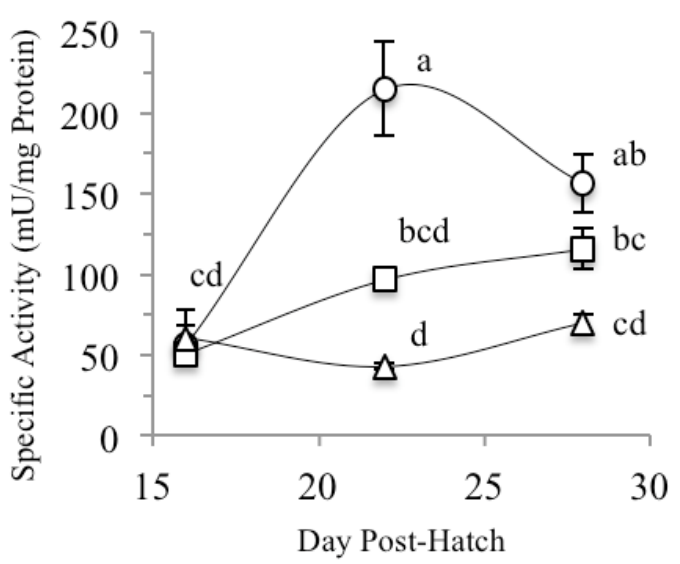

D) Amylase Intestinal Segment

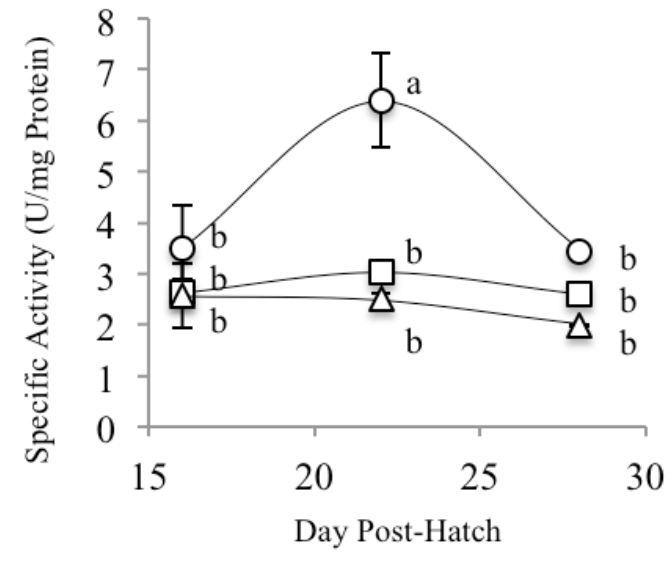

727

728 Figure 2

729 
A) Alkaline Phosphatase - BBM
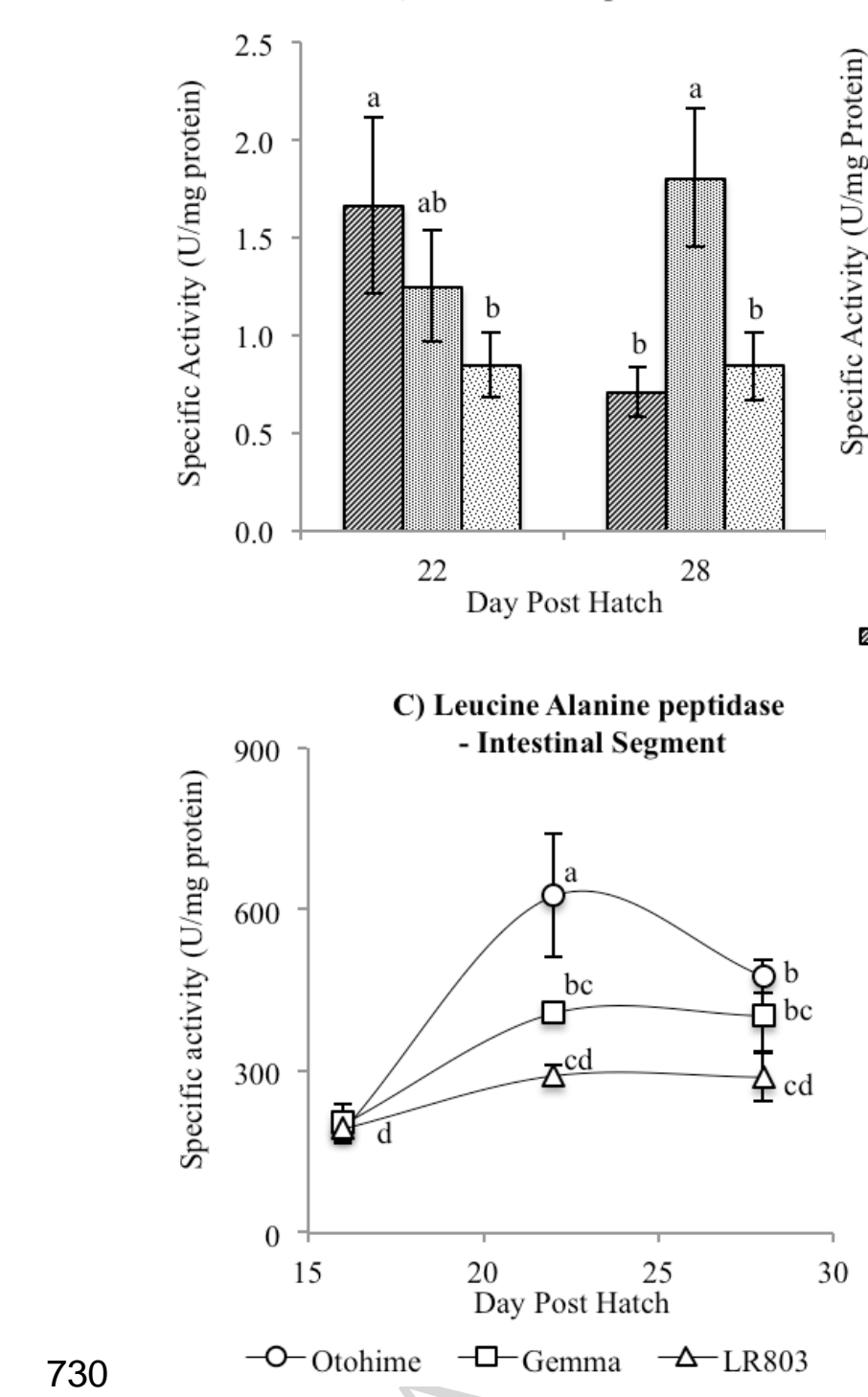

730

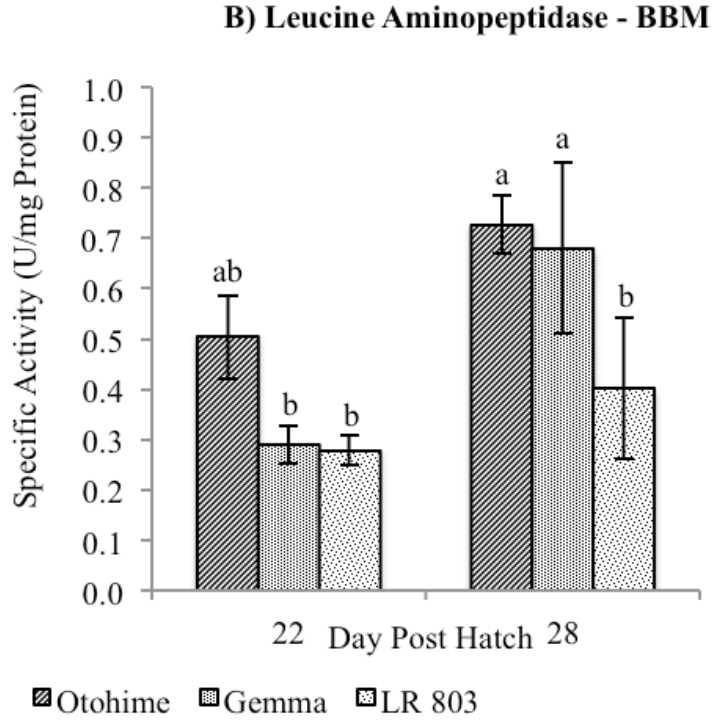

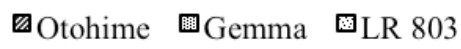

B) Leucine Aminopeptidase - BBM

731 Figure 3 
735

736

737

738

739

740

741

742

743

744

Highlights:

> Survival was similar for Florida pompano larvae weaned on three different diets

- Growth was enhanced by the Gemma diet compared to the two other diets

> Essential fatty acids ratios appeared more important than absolute inclusion levels

$>$ Enzyme analyses showed the full functionality of the pancreas by 16 days post hatch 
745 Table 1. Ingredients in the microdiets tested, as communicated by the manufacturer.

\begin{tabular}{ll}
\hline Microdiet & Ingredients \\
\hline
\end{tabular}

Otohime Krill meal, fish meal, squid meal, potato starch, wheat flour, fish oil, brewers yeast, calcium phosphate, guar gum, soy lecithin, betaine, licorice plant, apple extract, wheat germ.

Gemma Fish meal, algae, fish oils, lecithin, betaine, wheat gluten, vitamins, minerals.

LR803 Squid meal, krill meal, anchovy oil, lecithin, wheat gluten meal, vitamins, di-calcium phosphate, taurine, vitamin $\mathrm{C}$, astazanthin. 
Table 2. Proximate analysis (\% of wet weight) of the different microdiets and larvae (values \pm SEM, $n=4$ tanks, 10 pooled larvae per tank) at the end of the trial. Letters indicate significant differences within the same column (Tukey test; $p<0.05$ ).

\begin{tabular}{crrrr} 
Sample & \% Lipid & \% Protein & \% Moisture & \% Ash \\
\hline Gemma diet & $18.9^{\mathrm{b}} \pm 0.5$ & $57.6^{\mathrm{d}} \pm 0.1$ & $6.4^{\mathrm{b}} \pm 0.1$ & $10.8^{\mathrm{b}} \pm 0.1$ \\
Otohime diet & $21.2^{\mathrm{b}} \pm 1.6$ & $52.3^{\mathrm{c}} \pm 0.1$ & $6.4^{\mathrm{b}} \pm 0.1$ & $12.8^{\mathrm{c}} \pm 0.1$ \\
LR803 diet & $26.8^{\mathrm{c}} \pm 0.1$ & $50.9^{\mathrm{c}} \pm 0.1$ & $5.6^{\mathrm{a}} \pm 0.1$ & $3.7^{\mathrm{a}} \pm 0.1$ \\
Larvae fed Gemma diet & $9.9^{\mathrm{a}} \pm 0.8$ & $16.3^{\mathrm{b}} \pm 0.3$ & $61.4^{\mathrm{c}} \pm 0.3$ & $10.2^{\mathrm{b}} \pm 0.2$ \\
Larvae fed Otohime diet & $10.5^{\mathrm{a}} \pm 0.9$ & $16.1^{\mathrm{b}} \pm 0.3$ & $60.6^{\mathrm{c}} \pm 0.3$ & $10.8^{\mathrm{b}} \pm 0.6$ \\
Larvae fed LR803 diet & $10.7^{\mathrm{a}} \pm 0.6$ & $14.5^{\mathrm{a}} \pm 0.8$ & $61.6^{\mathrm{c}} \pm 0.2$ & $10.8^{\mathrm{b}} \pm 0.3$ \\
\hline
\end{tabular}


1 Table 3. Fatty acid profile of microdiets tested and the larvae sampled at the end of the trial

2 (values are \pm SEM, $\mathrm{n}=4$ tanks, 10 pooled larvae per tank). Letters indicate significant

3 differences within a same row (Tukey test, $\mathrm{p}<0.05$ ).

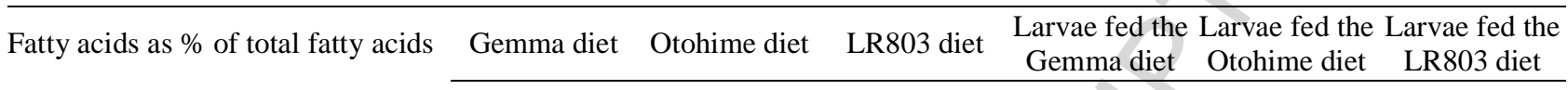

Saturated fatty acids

12:0 Lauric

14:0 Myristic

15:0 Pentadecanoic

16:0 Palmitic

17:0 Heptadecanoic

18:0 Stearic

\section{Total}

Mono-unsaturated fatty acids

15:1 cis-10 pentadecanoic

16:1n7 Palmitoleic

18:1n9 Oleic

18:1n7 Vaccenic

20:1n9 Eicosenoic acid

Total

Poly-unsaturated fatty acids

16:2n4 Hexadecadienoic

16:3n4 Hexadecatrienoic

18:2n6 Linoleic (LA)

18:3n6 $\gamma$-linolenic

18:3n4 Octadecatrienoic

18:3n3 $\alpha$-linolenic

18:4n3 Stearidonic

20:2n6 Eicosadienoic

20:3n6 Eicosatrienoic

20:4n6 Arachidonic (ARA)

20:3n3 Eicosatrienoic

20:4n3 Eicosatetraenoic

20:5n3 Eicosapentaenoic (EPA)

22:5n6 $\omega 6$ Docosapentaenoic

22:5n3 $\omega 3$ Docosapentanoic

22:6n3 Docosahexaenoic (DHA)

Total

Total $\omega 3$

Total $\omega 6$

$\omega 3 / \omega 6$ ratio

ARA/EPA ratio

DHA/EPA ratio

4

5

\begin{tabular}{|c|c|c|c|c|c|}
\hline $0.06^{\mathrm{c}} \pm 0.00$ & $0.14^{\mathrm{e}} \pm 0.00$ & $0.11^{\mathrm{d}} \pm 0.00$ & $0.03^{\mathrm{a}} \pm 0.00$ & $0.06^{\mathrm{c}} \pm 0.00$ & $0.05^{\mathrm{d}} \pm 0.00$ \\
\hline $2.97^{\mathrm{ab}} \pm 0.02$ & $7.40^{\mathrm{b}} \pm 0.05$ & $6.83^{\mathrm{ab}} \pm 0.04$ & $2.36^{\mathrm{a}} \pm 0.02$ & $4.64^{\mathrm{ab}} \pm 0.07$ & $3.72^{\mathrm{ab}} \pm 1.23$ \\
\hline $0.28^{\mathrm{a}} \pm 0.00$ & $0.46^{\mathrm{d}} \pm 0.00$ & $0.43^{\mathrm{cd}} \pm 0.00$ & $0.35^{\mathrm{b}} \pm 0.01$ & $0.33^{\mathrm{b}} \pm 0.01$ & $0.42^{\mathrm{c}} \pm 0.00$ \\
\hline $17.93^{\mathrm{a}} \pm 0.06$ & $18.34^{\mathrm{a}} \pm 0.05$ & $19.94^{\mathrm{b}} \pm 0.07$ & $21.25^{\mathrm{c}} \pm 0.17$ & $20.77^{\mathrm{bc}} \pm 0.28$ & $18.87^{\mathrm{a}} \pm 0.28$ \\
\hline $0.23^{\mathrm{a}} \pm 0.00$ & $0.23^{\mathrm{a}} \pm 0.00$ & $0.33^{c} \pm 0.00$ & $0.28^{b} \pm 0.01$ & $0.25^{\mathrm{ab}} \pm 0.01$ & $0.36^{\mathrm{d}} \pm 0.01$ \\
\hline $3.16^{\mathrm{a}} \pm 0.00$ & $3.09^{\mathrm{a}} \pm 0.01$ & $3.54^{\mathrm{a}} \pm 0.01$ & $5.55^{\mathrm{bc}} \pm 0.20$ & $5.90^{c} \pm 0.31$ & $4.80^{\mathrm{b}} \pm 0.11$ \\
\hline $24.62^{\mathrm{a}} \pm 0.08$ & $29.67^{b c} \pm 0.1$ & $31.17^{\mathrm{bc}} \pm 0.1$ & $29.81^{\mathrm{bc}} \pm 0.4$ & $31.95^{\mathrm{c}} \pm 0.6$ & $28.22^{\mathrm{b}} \pm 1.3$ \\
\hline $0.04^{\mathrm{a}} \pm 0.00$ & $0.09^{c} \pm 0.00$ & $0.07^{\mathrm{b}} \pm 0.00$ & $0.04^{\mathrm{a}} \pm 0.00$ & $0.07^{\mathrm{b}} \pm 0.00$ & $0.07^{\mathrm{b}} \pm 0.01$ \\
\hline $2.19^{\mathrm{a}} \pm 0.01$ & $5.26^{\mathrm{d}} \pm 0.02$ & $6.28^{\mathrm{e}} \pm 0.02$ & $2.40^{\mathrm{b}} \pm 0.02$ & $4.84^{\mathrm{c}} \pm 0.06$ & $6.38^{\mathrm{e}} \pm 0.06$ \\
\hline $11.72^{\mathrm{b}} \pm 0.02$ & $12.25^{\mathrm{b}} \pm 0.03$ & $9.92^{\mathrm{a}} \pm 0.02$ & $13.92^{\mathrm{c}} \pm 0.27$ & $15.59^{d} \pm 0.51$ & $11.24^{\mathrm{b}} \pm 0.07$ \\
\hline $1.47^{\mathrm{a}} \pm 0.01$ & $4.21^{c} \pm 0.02$ & $3.11^{\mathrm{b}} \pm 0.02$ & $1.42^{\mathrm{a}} \pm 0.06$ & $4.01^{\mathrm{c}} \pm 0.17$ & $3.46^{\mathrm{b}} \pm 0.03$ \\
\hline $3.23^{\mathrm{b}} \pm 0.00$ & $5.37^{\mathrm{c}} \pm 0.05$ & $0.98^{\mathrm{a}} \pm 0.01$ & $3.53^{\mathrm{b}} \pm 0.04$ & $3.75^{\mathrm{b}} \pm 0.26$ & $0.68^{\mathrm{a}} \pm 0.18$ \\
\hline $18.66^{\mathrm{a}} \pm 0.02$ & $27.18^{\mathrm{d}} \pm($ & $20.36^{\mathrm{b}} \pm 0.06$ & $21.30^{\mathrm{c}} \pm 0.2$ & $28.26^{\mathrm{e}} \pm 0.1$ & $21.84^{\mathrm{C}} \pm 0.15$ \\
\hline 0.4 & 0. & 0 & 1 & & .01 \\
\hline $0.29^{\mathrm{a}} \pm 0.00$ & $0.5^{\mathrm{c}} \pm 0$ & $0.99^{\mathrm{d}} \pm 0.00$ & $0.27^{\mathrm{b}} \pm 0.01$ & .02 & $74^{\mathrm{e}} \pm 0.01$ \\
\hline $30.40^{\mathrm{d}} \pm 0.05$ & $4.54^{\mathrm{a}} \pm 0.02$ & $19.84^{\mathrm{b}} \pm 0.04$ & $24.40^{c} \pm 0.32$ & $4.51^{\mathrm{a}} \pm 0.13$ & $20.06^{\mathrm{b}} \pm 0.06$ \\
\hline $0.03^{\mathrm{a}} \pm 0.01$ & $0.14^{\mathrm{b}} \pm 0.00$ & $0.21^{\mathrm{b}} \pm 0.00$ & $0.06^{\mathrm{a}} \pm 0.00$ & $0.17^{\mathrm{b}} \pm 0.00$ & $0.15^{\mathrm{b}} \pm 0.02$ \\
\hline $0.07^{\mathrm{a}} \pm 0.00$ & $0.16^{\mathrm{b}} \pm 0.00$ & $0.27^{\mathrm{c}} \pm 0.00$ & $0.12^{\mathrm{a}} \pm 0.01$ & $0.17^{\mathrm{b}} \pm 0.01$ & $0.34^{\mathrm{c}} \pm 0.02$ \\
\hline $3.59^{\mathrm{e}} \pm 0.01$ & $1.18^{\mathrm{b}} \pm 0.01$ & $3.08^{\mathrm{d}} \pm 0.01$ & $2.81^{\mathrm{c}} \pm 0.05$ & $1.07^{\mathrm{a}} \pm 0.01$ & $2.77^{\mathrm{c}} \pm 0.02$ \\
\hline $1.63^{\mathrm{b}} \pm 0.01$ & $2.53^{\mathrm{d}} \pm 0.01$ & $1.48^{\mathrm{b}} \pm 0.01$ & $0.92^{\mathrm{a}} \pm 0.03$ & $1.73^{\mathrm{bc}} \pm 0.02$ & $0.83^{\mathrm{a}} \pm 0.21$ \\
\hline $0.15^{\mathrm{a}} \pm 0.00$ & $0.15^{\mathrm{a}} \pm 0.00$ & $0.09^{\mathrm{a}} \pm 0.00$ & $0.78^{\mathrm{b}} \pm 0.04$ & $0.22^{\mathrm{a}} \pm 0.01$ & $0.30^{\mathrm{a}} \pm 0.10$ \\
\hline $0.05^{\mathrm{a}} \pm 0.00$ & $0.09^{\mathrm{b}} \pm 0.00$ & $0.20^{\mathrm{d}} \pm 0.02$ & $0.12^{\mathrm{bc}} \pm 0.01$ & .01 & $0.21^{\mathrm{d}} \pm 0.01$ \\
\hline $0.34^{\mathrm{a}} \pm 0.00$ & $0.54^{\mathrm{bc}} \pm 0.01$ & $0.55^{\mathrm{bc}} \pm 0.00$ & $0.30^{\mathrm{a}} \pm 0.01$ & $0.52^{\mathrm{b}} \pm 0.01$ & $0.59^{c} \pm 0.01$ \\
\hline $0.10^{\mathrm{a}} \pm 0.00$ & $0.16^{\mathrm{b}} \pm 0.00$ & $0.16^{\mathrm{b}} \pm 0.00$ & $0.26^{\mathrm{d}} \pm 0.01$ & $0.18^{\mathrm{b}} \pm 0.01$ & $0.21^{\mathrm{c}} \pm 0.01$ \\
\hline $0.30^{\mathrm{a}} \pm 0.00$ & $0.56^{\mathrm{b}} \pm 0.01$ & $0.56^{\mathrm{b}} \pm 0.03$ & $0.56^{\mathrm{b}} \pm 0.02$ & $1.03^{\mathrm{d}} \pm 0.03$ & $0.87^{\mathrm{c}} \pm 0.03$ \\
\hline $4.12^{\mathrm{b}} \pm 0.03$ & $10.79^{\mathrm{f}} \pm 0.05$ & $9.01^{\mathrm{e}} \pm 0.08$ & $2.21^{\mathrm{a}} \pm 0.04$ & $7.28^{\mathrm{d}} \pm 0.08$ & $6.10^{c} \pm 0.13$ \\
\hline $0.17^{\mathrm{c}} \pm 0.00$ & $0.10^{\mathrm{a}} \pm 0.01$ & $0.16^{\mathrm{bc}} \pm 0.00$ & $0.18^{\mathrm{c}} \pm 0.01$ & $0.14^{\mathrm{b}} \pm 0.00$ & $0.20^{\mathrm{d}} \pm 0.00$ \\
\hline $0.59^{\mathrm{a}} \pm 0.01$ & $0.95^{\mathrm{b}} \pm 0.00$ & $1.18^{\mathrm{c}} \pm 0.00$ & $1.01^{\mathrm{b}} \pm 0.04$ & $2.58^{\mathrm{d}} \pm 0.06$ & $2.55^{\mathrm{d}} \pm 0.05$ \\
\hline $7.32^{\mathrm{b}} \pm 0.05$ & $9.57^{c} \pm 0.01$ & $5.36^{\mathrm{a}} \pm 0.01$ & $7.37^{\mathrm{b}} \pm 0.11$ & $11.22^{\mathrm{d}} \pm 0.29$ & $7.12^{\mathrm{b}} \pm 0.13$ \\
\hline $49.60^{\mathrm{d}} \pm 0.09$ & $32.69^{\mathrm{a}} \pm 0.04$ & $44.54^{\mathrm{c}} \pm 0.1$ & $41.75^{\mathrm{b}} \pm 0.5$ & $32.06^{\mathrm{a}} \pm 0.34$ & $44.06^{\mathrm{C}} \pm 0.37$ \\
\hline $17.66^{\mathrm{b}} \pm 0.09$ & $25.73^{\mathrm{d}} \pm 0.06$ & 99 & $15.14^{\mathrm{a}} \pm 0.2$ & $25.09^{\mathrm{d}} \pm 0.35$ & $20.44^{\mathrm{c}} \pm 0.23$ \\
\hline & & & 25.84 & & 0.15 \\
\hline $0.57^{\mathrm{a}} \pm 0.00$ & $4.63^{c} \pm 0.02$ & $0.99^{\mathrm{b}} \pm 0.00$ & $0.59^{\mathrm{a}} \pm 0.01$ & $4.40^{c} \pm 0.13$ & $0.95^{\mathrm{b}} \pm 0.01$ \\
\hline $0.08^{\mathrm{d}} \pm 0.00$ & 0.0 & $0.06^{\mathrm{b}} \pm 0.00$ & $0.14^{\mathrm{f}} \pm 0.00$ & & $1^{\mathrm{e}} \pm$ \\
\hline $1.78^{\mathrm{e}} \pm 0.01$ & $0.89^{\mathrm{b}} \pm 0.00$ & $0.59^{\mathrm{a}} \pm 0.01$ & $3.33^{\mathrm{f}} \pm 0.08$ & $1.54^{\mathrm{d}} \pm 0.05$ & $1.17^{\mathrm{c}} \pm 0.03$ \\
\hline
\end{tabular}

